\title{
Groundwater quality around Tummalapalle area, Cuddapah District, Andhra Pradesh, India
}

\author{
Y. Sreedhar ${ }^{1} \cdot$ A. Nagaraju ${ }^{1}$
}

Received: 26 November 2016/ Accepted: 17 April 2017/Published online: 26 April 2017

(c) The Author(s) 2017. This article is an open access publication

\begin{abstract}
The suitability of groundwater for drinking and irrigation was assessed in Tummalapalle area. Forty groundwater samples were analysed for major cations, anions and other parameters such as $\mathrm{pH}$, electrical conductivity, total dissolved solids (TDS), total alkalinity and total hardness (TH). The parameters such as sodium adsorption ratio, adjusted sodium adsorption ratio (adj.SAR), per cent sodium, potential salinity, residual sodium carbonate, non-carbonate hardness, Kelly's ratio and permeability index were calculated for the evaluation of irrigation water quality. Groundwater chemistry was also analysed by statistical analysis, USSL, Wilcox, Doneen, Piper and Chadhas diagrams, to find out their suitability for irrigation. TDS and TH were used as main parameters to interpret the suitability of groundwater for drinking purpose. The correlation coefficient matrix between the hydrochemical parameters was carried out using Pearson's correlation to infer the possible water-rock interactions responsible for the variation of groundwater chemistry and this has been supported by Gibbs diagram. The results indicate that the groundwater in Tummalapalle area is alkaline in nature. $\mathrm{Ca}-\mathrm{Mg}-\mathrm{HCO}_{3}$ is the dominant hydrogeochemical facies. Water chemistry of the study area strongly reflects the dominance of weathering of rockforming minerals such as bicarbonates and silicates. All parameters and diagrams suggest that the water samples of the study are good for irrigation, and the plots of TDS and TH suggest that $12.5 \%$ of the samples are good for human consumption.
\end{abstract}

\section{A. Nagaraju}

arveti@yahoo.com

1 Department of Geology, S V University, Tirupati, Andhra Pradesh 517 502, India
Keywords Hydrogeochemistry · Water quality . Tummalapalle $\cdot$ Andhra Pradesh

\section{Introduction}

Water is an indispensable natural resource on earth. Safe drinking water is the primary need of every human and also their basic fundamental right (Nagaraju et al. 2015, 2016c; $\mathrm{Li}$ et al. 2015). Fresh water has become a scarce commodity due to over exploitation and pollution of water. Groundwater is the most important source of water supply for drinking, agriculture, irrigation and industrial purposes (Gupta and Sunita 2009; Bhattacharya et al. 2012; Li et al. 2013a, 2014a; Nagaraju et al. 2013, 2014a, 2016a, b; Wu and Sun 2016). There is a growing awareness of the environmental legacy of mining activities that have been undertaken with little concern for the environment (Mahesh et al. 2001; Brindha et al. 2010; Tripathi et al. 2011). Mine water can vary greatly in the concentration of contaminants present, and some mine water discharges can be a potential water resource, where the local water demands for industrial, irrigation and even drinking and domestic uses can be fulfilled by effective utilization (Cidu et al. 2007; Manish Kumar et al. 2007; Suresh et al. 2007; Li et al. 2013b; Nagaraju et al. 2006, 2014b, 2015; Wu et al. 2014).

Metal pollution by mining and associated industrial activities is somewhat mitigated today by strict implementation of clean technology and environmental measures. The drastic increase in population, urbanization and modern land-use applications and demands for water supply has limited the globally essential groundwater resources in terms of both its quality and quantity. Further, the 
quality is a function of the physical, chemical and biological parameters, and can be subjective, since it depends on a specific intended use (Ravikumar and Somashekar 2013). Tummalapalle is a famous uranium mining area in India, and the mining activities generally cause groundwater pollution. Therefore, the purpose of this paper is to summarize groundwater quality in and around Tummalapalle uranium mining area and focus its impact on water quality for irrigation and drinking purpose.

\section{Geology of the study area}

Geologically, Tummalapalle area is in the south-western part of the Cuddapah basin. Tummalapalle $\left(14^{\circ} 18^{\prime}\right.$ to $14^{\circ} 24^{\prime} \mathrm{N} ; 78^{\circ} 13^{\prime} 30^{\prime \prime}$ to $78^{\circ} 22^{\prime} 30^{\prime \prime} \mathrm{E}$ ) is located in Pulivendla Taluk of Cuddapah District of Andhra Pradesh (Fig. 1). It is included in the Survey of India topo sheet No. $57 \mathrm{~J} / 7$. Lithologically, the Vempalle Formation consists of purple shale, massive limestone, intraformational conglomerate, dolostone (uraniferous), shale and cherty limestone. The radioactive minerals identified in the ore zone are pitchblende, coffinite and $\mathrm{U}-\mathrm{Ti}$ complex. The impersistent conglomerate and purple shale band occurring immediately below and above the mineralized rock, respectively, serve as the marker horizons (Geological Survey of India 2001; Basu 2007).

\section{Climate and rainfall}

In this area, the climate is tropical with seasonal rainfall. This area has rather a hot summer with temperature as high as $42{ }^{\circ} \mathrm{C}$ and minimum temperature being $15^{\circ} \mathrm{C}$. This region is known for its wide variation in contour, heavy vegetation, low rainfall and significant variation in meteorological parameters. The average annual rainfall of the Cuddapah District is about $710 \mathrm{~mm}$ and it ranges from nil rainfall in January to $137 \mathrm{~mm}$ in October and this is the wettest month of the year. The mean seasonal rainfall distribution is $402.4 \mathrm{~mm}$ in south-west monsoon (JuneSeptember) and in north-east monsoon (October-December) this is about $239.1 \mathrm{~mm}$. The percentage distribution of rainfall is about $56.7 \%$ in south-west monsoon and $33.7 \%$ in north-east monsoon (Central Ground Water Board 2013).

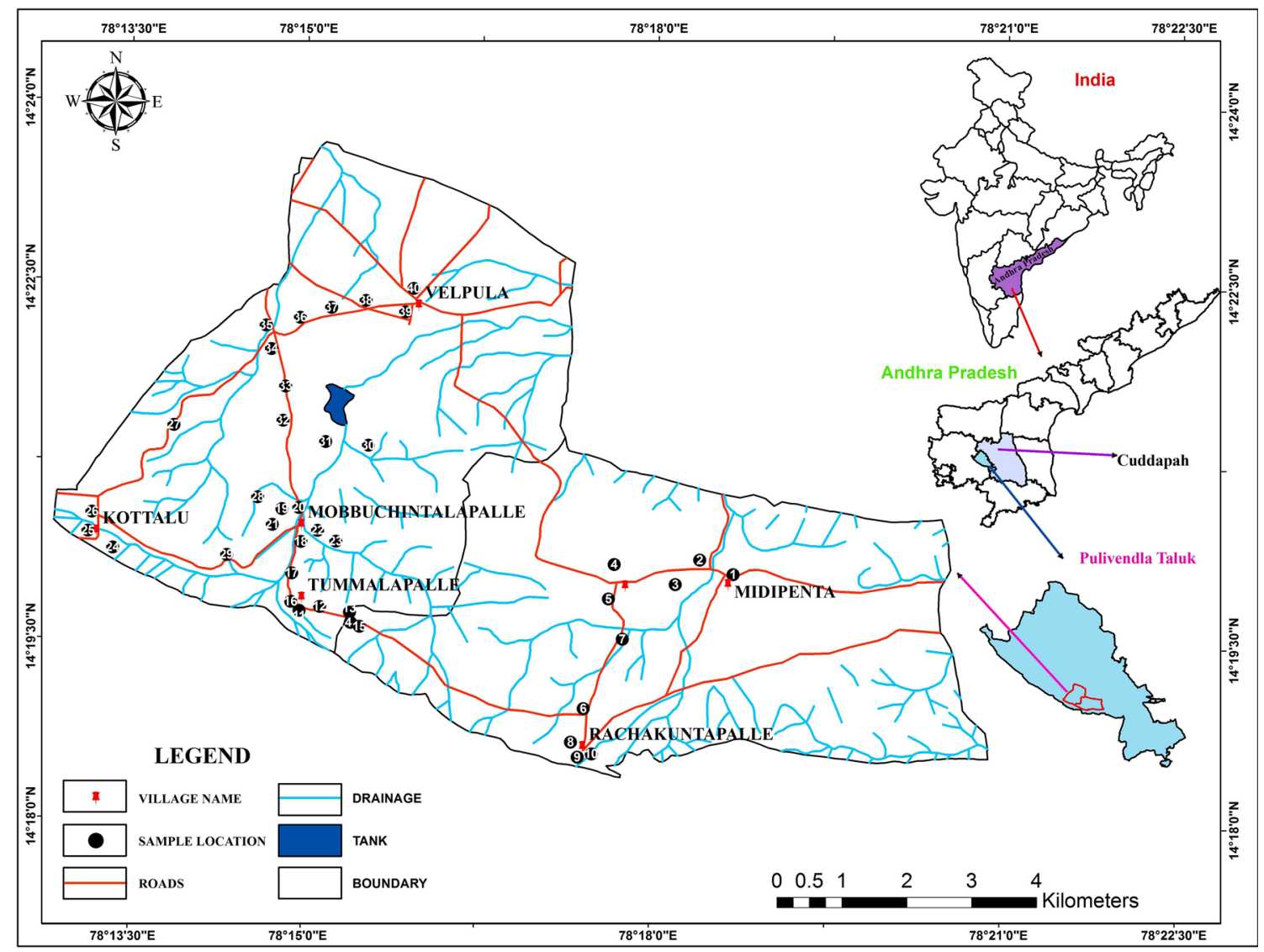

Fig. 1 Map of study area showing sampling locations 


\section{Hydrogeology}

Groundwater occurs under water table conditions in the weathered zones of Papaghni and Chitravati group of rocks. The water present in the dug wells is mainly due to the numerous joints, fractures and fissures present in these rock types. The quartzites and the basal part of the massive limestone are good aquifers, and the permanent water table in these is generally shallow. Water is alkaline in nature and suits both for irrigation and drinking purposes (Geological Survey of India 2001). It is found that the groundwater in the Tummalapalle village is saline due to unhygienic conditions, since water found away from the village in surrounding area is generally sweet. The depth of water level is observed between 10 and $20 \mathrm{~m}$ in Vemula mandal (Central Ground Water Board 2007, 2013).

\section{Methodology}

Water samples were collected in and around the Tummalapalle uranium mining area. Sampling was carried out in the month of May 2014. A total of 40 groundwater samples were collected. Sampling locations were recorded using a potable GPS device and they are shown in Fig. 1. Samples were collected in precleaned and well-dried polyethylene bottles. The water samples collected in the field were analysed for electrical conductivity (EC), $\mathrm{pH}$, total dissolved solids (TDS), major cations such as calcium, magnesium, sodium and potassium, and anions such as bicarbonate, carbonate, chloride, fluoride and sulphate, adopting the standard methods (Hem 1985; Raghunath 1987; APHA 2012). The sampling methods are chosen according to the objectives of the investigation and the geology (lithology, hydrogeology, foreign materials) of the area. The chemical quality data are shown in Table 1. Pearson correlation coefficient was calculated for measuring the strength of the linear relationship between these parameters. Various methods and graphs were used to study and interpret the water analyses data.

\section{Results and discussion}

Geochemical properties and principles that govern the behaviour of dissolved chemical constituents in groundwater are referred to as hydrogeochemistry. The dissolved constituents occur as ions, molecules or solid particles. The chemical composition of groundwater is related to the solid product of rock weathering and changes with respect to time and space. Hence, the variation in the concentration levels of the different hydrogeochemical constituents determines its usefulness for domestic, industrial and agricultural purposes. The minimum, maximum, average, SD and SE values of the hydrochemical data of the study area are shown in Table 1 along with the calculated parameters of the hydrogeochemical data.

\section{Groundwater chemistry}

From Table 1, it is evident that in the study area, the $\mathrm{pH}$ is in the range of 6.70-7.90 and the EC is ranging from 1210 to $2240 \mu \mathrm{mhos} / \mathrm{cm}$. Calcium is varying from 25 to $173 \mathrm{mg} /$ 1 and magnesium is ranging from 27 to $133 \mathrm{mg} / \mathrm{l}$; sodium is between 6 and $86 \mathrm{mg} / \mathrm{l}$ and potassium is varying from 2 to $73 \mathrm{mg} / \mathrm{l}$. The fluoride concentration is ranging from 0.11 to $0.62 \mathrm{mg} / \mathrm{l}$. The total dissolved solids lie between 787 and $1456 \mathrm{mg} / \mathrm{l}$. The concentration of sulphate varies between 8 and $94 \mathrm{mg} / \mathrm{l}$. The bicarbonate and carbonate concentrations in groundwater ranges from 130 to $509 \mathrm{mg} / \mathrm{l}$ and 38 to $222 \mathrm{mg} / \mathrm{l}$, respectively. The chloride content varies from 21 to $207 \mathrm{mg} / \mathrm{l} /$. The alkalinity varies from 36 to $144 \mathrm{mg} / \mathrm{l}$ and the hardness values vary from 120 to $596 \mathrm{mg} / \mathrm{l}$. The abundance of the major ions in groundwater is in following order:

$$
\begin{aligned}
\mathrm{Ca}^{2+} & >\mathrm{Mg}^{2+}>\mathrm{Na}^{+}>\mathrm{K}^{+} \text {and } \mathrm{HCO}_{3}^{-}>\mathrm{CO}_{3}^{-} \\
& >\mathrm{Cl}^{-}>\mathrm{SO}_{4}^{2-}>\mathrm{F}^{-}
\end{aligned}
$$

\section{Classification of groundwater}

\section{Piper trilinear diagram}

Piper $(1944,1953)$ based on the concentration of dominant cations and anions have proposed a trilinear diagram to show the percentages at mill equivalents per litre of cations and anions in water samples. The Piper diagram was modified by Davis and Dewiest (1967). This is useful to understand the total chemical character of water samples in terms of cation-anion pairs. The Piper diagram reveals similarities and differences among groundwater samples because those with similar qualities will tend to plot together as groups (Walton 1970). The Piper diagram consists of two triangular and one intervening diamondshaped field (Fig. 2). The percentage reacting values at the three cation groups- $\mathrm{Ca}, \mathrm{Mg}$ and $(\mathrm{Na}+\mathrm{K})$ - are plotted as a single point in the left triangular field and the three anion groups- $\left(\mathrm{HCO}_{3}+\mathrm{CO}_{3}\right), \mathrm{SO}_{4}$ and $\mathrm{Cl}-$ similarly on the right triangular field.

In the present study, it is clear that about $42.5 \%$ samples are falling in the area of 5 and this indicates that carbonate hardness (secondary alkalinity) exceeds $50 \%$. About $37.5 \%$ samples are falling in the area of 9 and this indicates that 
Table 1 Descriptive statistics for groundwater samples of Tummalapalle area

\begin{tabular}{|c|c|c|c|c|c|c|}
\hline S. No. & Constituents & Min & $\operatorname{Max}$ & Average & SD & SE \\
\hline 1 & Calcium (Ca) (ppm) & 25 & 173 & 77 & 26.06 & 4.12 \\
\hline 2 & Magnesium (Mg) (ppm) & 27 & 133 & 66 & 23.33 & 3.69 \\
\hline 3 & Sodium (Na) (ppm) & 6 & 86 & 33 & 16.72 & 2.64 \\
\hline 4 & Potassium (K) (ppm) & 2 & 73 & 14 & 14.99 & 2.37 \\
\hline 5 & Bicarbonate $\left(\mathrm{HCO}_{3}\right)(\mathrm{ppm})$ & 130 & 509 & 303 & 79.75 & 12.61 \\
\hline 6 & Carbonate $\left(\mathrm{CO}_{3}\right)(\mathrm{ppm})$ & 38 & 222 & 113 & 36.01 & 5.69 \\
\hline 7 & Sulphate $\left(\mathrm{SO}_{4}\right)(\mathrm{ppm})$ & 8 & 94 & 17 & 15.56 & 2.46 \\
\hline 8 & Chloride $(\mathrm{Cl})(\mathrm{ppm})$ & 21 & 207 & 71 & 42.86 & 6.78 \\
\hline 9 & Fluoride (ppm) & 0.11 & 0.62 & 0.40 & 0.10 & 0.02 \\
\hline 10 & $\mathrm{pH}$ & 6.70 & 7.90 & 7.30 & 0.23 & 0.04 \\
\hline 11 & Specific conductance $\left(\mu \mathrm{mhoscm}^{-1}\right)$ & 1210 & 2240 & 1884 & 240.58 & 38.04 \\
\hline 12 & Total dissolved solids (ppm) & 787 & 1456 & 1225 & 156.38 & 24.73 \\
\hline 13 & Hardness as $\mathrm{CaCO}_{3}(\mathrm{ppm})$ & 120 & 596 & 296 & 103.24 & 16.32 \\
\hline 14 & Alkalinity as $\mathrm{CaCO}_{3}(\mathrm{ppm})$ & 36 & 144 & 89 & 20.44 & 3.23 \\
\hline 15 & Sodium adsorption ratio (SAR) & 0.15 & 1.54 & 0.67 & 0.33 & 0.05 \\
\hline 16 & Adjusted SAR (adj.SAR) & 0.33 & 4.59 & 1.79 & 0.89 & 0.14 \\
\hline 17 & Sodium percentage & 4.73 & 35.03 & 15.86 & 6.79 & 1.07 \\
\hline 18 & Potential salinity & 0.72 & 6.13 & 2.17 & 1.20 & 0.19 \\
\hline 19 & Residual sodium carbonate & -3.92 & 1.03 & -0.60 & 0.93 & 0.15 \\
\hline 20 & Permeability index (PI) & 23.97 & 55.20 & 34.72 & 6.58 & 1.04 \\
\hline 21 & Kelly's ratio & 0.04 & 0.50 & 0.16 & 0.09 & 0.01 \\
\hline 22 & Non-carbonate hardness (ppm) & -51.29 & 195.82 & 29.90 & 46.55 & 7.36 \\
\hline
\end{tabular}

none of the cation and anion pairs exceed 50\%. About $20 \%$ samples are falling in the area of 6 which indicates that non-carbonate hardness (secondary salinity) exceeds $50 \%$. The Piper diagram confirms that all the groundwaters in the study area are characterized as alkaline earth's $(\mathrm{Ca}+\mathrm{Mg})$ exceeds alkalies $(\mathrm{Na}+\mathrm{K})$ and weak acids $\left(\mathrm{CO}_{3}+\mathrm{HCO}_{3}\right)$ exceed strong acids $\left(\mathrm{SO}_{4}+\mathrm{Cl}+\mathrm{F}\right)$. This is due to the dolomitic rocks which are responsible for release of chemical elements into the groundwaters of the Tummalapalle area.

\section{Chadhas diagram}

The groundwater of the study area has been classified as per Chadha's diagram (Chadha 1999). This diagram is a somewhat modified version of the Piper diagram (Piper 1944) and the expanded Durov diagram (Durov 1948). In Chadha's diagram, the difference in milliequivalent percentage between alkaline earths $\left(\mathrm{Ca}^{2+}+\mathrm{Mg}^{2+}\right)$ and alkali metals $\left(\mathrm{Na}^{+}+\mathrm{K}^{+}\right)$, expressed as percentage reacting values, is plotted on the $X$ axis and the difference in milliequivalent percentage between weak acidic anions $\left(\mathrm{CO}_{3}{ }^{2-}+\mathrm{HCO}_{3}{ }^{-}\right)$and strong acidic anions $\left(\mathrm{Cl}^{-}+\right.$ $\mathrm{SO}_{4}{ }^{2-}$ ) is plotted on the $Y$ axis (Fig. 3). The square rectangular field describes the overall character of the water.
The diagram has all the advantage of the diamond-shaped field of the piper trilinear diagram and can be used to study various hydrochemical processes, such as base cation exchange, cement pollution, mixing of natural waters, sulphate reduction, saline water (end product water) and other related hydrochemical problem (Jain et al. 2001). In the present study, all the samples are falling in the field of 5 which belongs to the $\mathrm{Ca}^{2+}-\mathrm{Mg}^{2+}-\mathrm{HCO}_{3}{ }^{-}$type and such water has temporary hardness (Fig. 3).

\section{Statistical analysis}

Correlation between the different parameters of groundwater of Tummalapalle showed both positive and inverse relations between the parameters, some moderately correlated and some well correlated (Table 2). Highest positive correlation was observed among these parameters: hardness and $\mathrm{Mg}$ (1.00); hardness and $\mathrm{CO}_{3}$ (0.905); hardness and $\mathrm{HCO}_{3}(0.869) ; \mathrm{HCO}_{3}$ and $\mathrm{CO}_{3}(0.968) ; \mathrm{Mg}$ and $\mathrm{CO}_{3}$ (0.900); $\mathrm{Mg}$ and $\mathrm{HCO}_{3}$ (0.865). The high correlations among these parameters indicate that carbonates dissolution may be the dominant water-rock interaction occurring in the aquifer ( $\mathrm{Li}$ et al. 2013a), which can be expressed by R1 and R3. Apart from these highly correlated parameters, there were other moderate correlations between other 
Fig. 2 Trilinear diagram for representing the analyses of groundwater quality (Piper diagram)

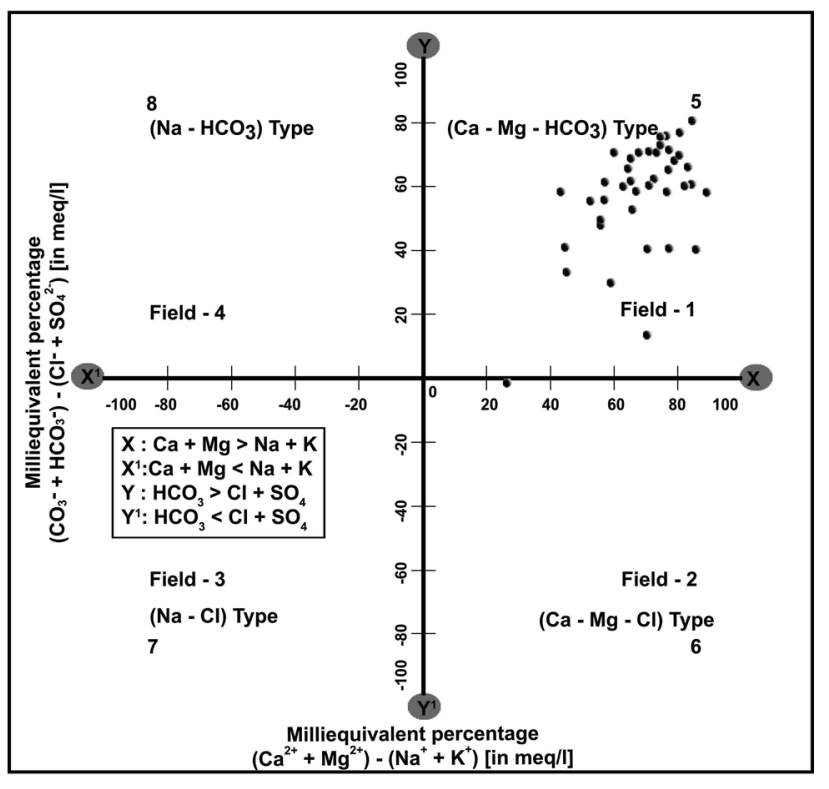

Fig. 3 Chadha's diagram (modified piper diagram)

parameters, such as $\mathrm{Cl}$ and $\mathrm{Na}(0.739), \mathrm{HCO}_{3}$ and $\mathrm{Na}$ (0.418), and $\mathrm{F}$ and $\mathrm{Ca}(0.378)$. The positive correlation between $\mathrm{Cl}$ and $\mathrm{Na}$ suggests that halite weathering (R3) is one of the reasons responsible for the concentration of $\mathrm{Na}$ and $\mathrm{Cl}$ in groundwater ( $\mathrm{Li}$ et al. 2016a). Similarly, the positive correlation between $\mathrm{HCO}_{3}$ and $\mathrm{Na}$ indicates that the dissolution of albite, expressed in $\mathrm{R} 4$, is a possible origin of $\mathrm{HCO}_{3}$ and $\mathrm{Na}$ in groundwater ( $\mathrm{Li}$ et al. 2016b). The moderate correlation between $\mathrm{F}$ and $\mathrm{Ca}$ may be attributed to the dissolution of fluorite ( $\mathrm{Li}$ et al. 2014b; Wu et al. 2015). Overall, the major chemical elements present in the groundwaters of the Tummalapalle area are due to the dolomitic rocks occurring in the study area.

$$
\begin{aligned}
& \mathrm{CaCO}_{3}+\mathrm{CO}_{2}+\mathrm{H}_{2} \mathrm{O} \rightarrow \mathrm{Ca}^{2+}+2 \mathrm{HCO}_{3}^{-} \\
& \quad \mathrm{CaMg}\left(\mathrm{CO}_{3}\right)_{2}+2 \mathrm{CO}_{2}+2 \mathrm{H}_{2} \mathrm{O} \\
& \quad \rightarrow \mathrm{Mg}^{2+}+\mathrm{Ca}^{2+}+4 \mathrm{HCO}_{3}^{-} \\
& \mathrm{NaCl} \rightarrow \mathrm{Na}^{+}+\mathrm{Cl}^{-} \\
& \quad 2 \mathrm{NaAlSi}_{3} \mathrm{O}_{8}+2 \mathrm{CO}_{2}+11 \mathrm{H}_{2} \mathrm{O} \\
& \rightarrow \mathrm{Al}_{2} \mathrm{Si}_{2} \mathrm{O}_{5}(\mathrm{OH})_{4}+4 \mathrm{H}_{4} \mathrm{SiO}_{4}+2 \mathrm{Na}_{+}+2 \mathrm{HCO}_{3}^{-}
\end{aligned}
$$

$\mathrm{CaF}_{2}=\mathrm{Ca}^{2+}+2 \mathrm{~F}^{-}$.

\section{Drinking water quality assessment}

Total dissolved solids (TDS) and total hardness (TH) are two important parameters in assessing drinking water quality. TDS represents the total weight of dissolved solids 
Table 2 Correlation matrix for groundwater samples of Tummalapalle area

\begin{tabular}{|c|c|c|c|c|c|c|c|c|c|c|c|c|c|c|}
\hline & $\mathrm{EC}$ & $\mathrm{pH}$ & $\mathrm{Ca}$ & $\mathrm{Mg}$ & $\mathrm{Na}$ & $\mathrm{K}$ & $\mathrm{HCO}_{3}$ & $\mathrm{CO}_{3}$ & $\mathrm{Cl}$ & $\mathrm{SO}_{4}$ & $\mathrm{~F}$ & TDS & Hardness & Alkalinity \\
\hline $\mathrm{EC}$ & 1 & & & & & & & & & & & & & \\
\hline $\mathrm{pH}$ & $0.488^{* * *}$ & 1 & & & & & & & & & & & & \\
\hline $\mathrm{Ca}$ & 0.122 & 0.045 & 51 & & & & & & & & & & & \\
\hline $\mathrm{Mg}$ & -0.151 & -0.020 & $0.455^{* *}$ & 1 & & & & & & & & & & \\
\hline $\mathrm{Na}$ & 0.128 & -0.248 & 80.300 & 0.303 & 1 & & & & & & & & & \\
\hline K & -0.157 & -0.231 & 10.028 & 0.306 & $0.361^{*}$ & 1 & & & & & & & & \\
\hline $\mathrm{HCO}_{3}$ & -0.031 & 0.007 & $170.695^{* *}$ & $0.865^{* *}$ & $0.418^{* *}$ & $0.392^{*}$ & 1 & & & & & & & \\
\hline $\mathrm{CO}_{3}$ & -0.042 & 0.027 & $70.678^{* *}$ & $0.900^{* *}$ & $0.391^{*}$ & 0.308 & $0.968^{* *}$ & 1 & & & & & & \\
\hline $\mathrm{Cl}$ & -0.049 & -0.291 & $10.544^{* *}$ & $0.475^{* *}$ & $0.739^{* *}$ & $0.361^{*}$ & $0.460^{* *}$ & $0.434^{* *}$ & 1 & & & & & \\
\hline $\mathrm{SO}_{4}$ & 0.142 & 0.179 & 90.097 & 0.221 & -0.219 & -0.157 & 0.010 & 0.103 & -0.108 & 1 & & & & \\
\hline $\mathrm{F}$ & 0.176 & 0.046 & $60.378^{*}$ & -0.086 & 0.128 & -0.083 & 0.132 & 0.083 & 0.155 & -0.232 & 1 & & & \\
\hline TDS & $0.359^{*}$ & 0.094 & $40.318^{*}$ & -0.019 & $0.327^{*}$ & 0.136 & 0.174 & 0.121 & 0.241 & -0.002 & $0.346^{*}$ & 1 & & \\
\hline Hardness & -0.151 & -0.020 & $0.467^{* *}$ & $1.000^{* *}$ & 0.303 & 0.304 & $0.869^{* *}$ & $0.905^{* *}$ & $0.478^{* *}$ & 0.222 & -0.082 & -0.017 & 1 & \\
\hline Alkalinity & $0.440^{* *}$ & 0.157 & 70.298 & 0.031 & $0.315^{*}$ & $0.440^{* *}$ & 0.309 & 0.153 & 0.255 & -0.171 & 0.197 & $0.456^{* *}$ & 0.032 & 1 \\
\hline
\end{tabular}

** Correlation is significant at the 0.01 level (two-tailed)

* Correlation is significant at the 0.05 level (two-tailed)

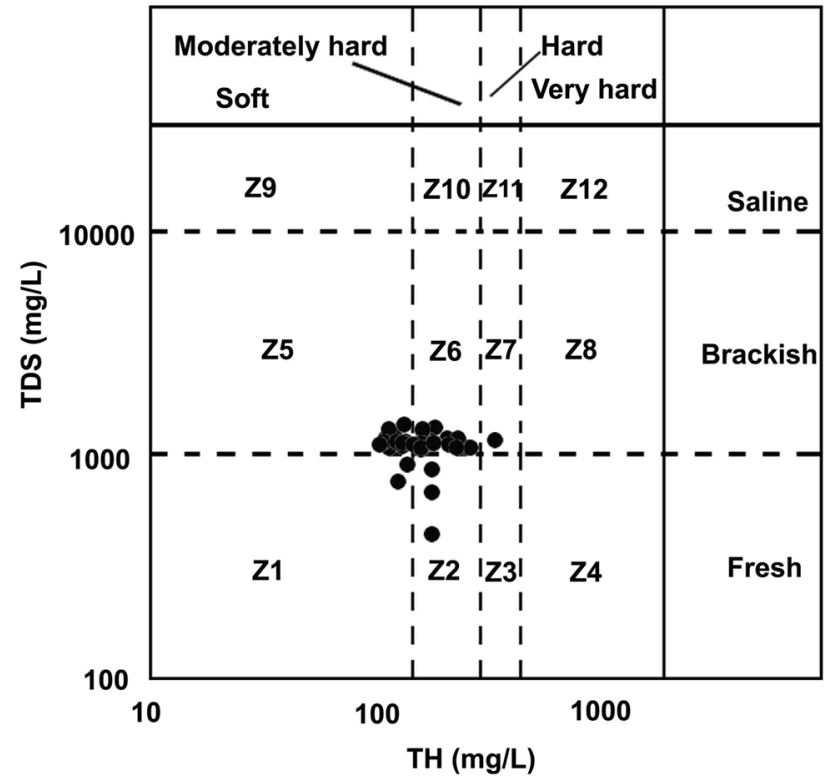

Fig. 4 Plot of TDS vs TH expressed in $\mathrm{mg} / \mathrm{l}$ as $\mathrm{CaCO}_{3}$

in a solution and expresses the degree of salinity of a medium (Mitra et al. 2007). According to the level of TDS, groundwater can be classified as fresh groundwater $($ TDS $<1000 \mathrm{mg} / \mathrm{L}), \quad$ brackish water $(1000>$ TDS $<$ $10000 \mathrm{mg} / \mathrm{L}$ ) and saline water (TDS $>10000 \mathrm{mg} / \mathrm{L}$ ) (Wanda et al. 2011). Hardness is a measure of dissolved $\mathrm{Ca}^{2+}$ and $\mathrm{Mg}^{2+}$ in water and is expressed as $\mathrm{CaCO}_{3}$. According to the grading standards of $\mathrm{TH}\left(\right.$ as $\left.\mathrm{CaCO}_{3}\right)$, groundwater can be classified as soft water ( $\mathrm{TH}<150 \mathrm{mg} /$ $\mathrm{L})$, moderately hard water $(150<\mathrm{TH}<300 \mathrm{mg} / \mathrm{L})$, hard water $(300<\mathrm{TH}<450 \mathrm{mg} / \mathrm{L})$ and very hard water (TH $>450 \mathrm{mg} / \mathrm{L})(\mathrm{Li}$ et al. 2011, 2012). The plot of total dissolved soils vs hardness vs TH suggests that the groundwater samples lie in the zones Z1, Z2, Z5, Z6 and one sample in Z7, indicating different quality levels among these samples (Fig. 4). Samples belonging to zones of Z1 and $\mathrm{Z} 2$ (12.5\% samples) are suitable for human consumption because they are fresh water with acceptable degrees of hardness. However, the samples that belong to zones of Z5 (27.5\% samples) and Z6 (57.5\% samples) are soft and moderately hard with slightly saline.

\section{Irrigation water quality}

\section{Sodium adsorption ratio (SAR)}

Sodium hazard is also usually expressed in terms of the sodium adsorption ratio (SAR), which is calculated from the ratio of sodium to calcium and magnesium (Todd and Mays 2005; Li et al. 2013a). The SAR is an important parameter for the determination of the suitability of irrigation water because it is responsible for the sodium hazard (Li et al. 2016c, d; Todd and Mays 2005). The waters were classified in relation to irrigation based on the ranges of SAR values (Richards 1954). Continued use of water having a high SAR leads to a breakdown in the physical structure of the soil. Sodium is adsorbed and becomes attached to soil particles. The soil then becomes hard and compact when dry and increasingly impervious to water 
penetration. The degree to which irrigation water tends to enter into cation-exchange reactions in soil can be indicated by the sodium adsorption ratio. Sodium replacing adsorbed calcium and magnesium is a hazard as it causes damage to the soil structure.

SAR is computed as

$\mathrm{SAR}=\frac{\mathrm{Na}}{\sqrt{\mathrm{Ca}+\mathrm{Mg} / 2}}$

where all ionic concentration is expressed in meq/l.

The SAR values of the study area are presented in Table 1 and are varying from 0.15 to 1.54 . Groundwater could be also classified based on sodium adsorption ratio (SAR) as excellent (10), good (10-18), doubtful (18-26) and unsuitable ( $>26$ ) (Sadashivaiah et al. 2008). A high SAR in irrigation water has the potential to impair soil structure and thus the permeability of the soil leading to a lack of soil moisture (Compton 2011). The sodium adsorption ratio (SAR) greater than 12.0 is considered sodic and threatens the survival of vegetation by increasing soil swelling (dispersion) and reducing soil permeability (Kuipers et al. 2004).

\section{Integrated effect of EC and SAR}

Richard's classification of sodium adsorption ratio proposes that the groundwaters of the study area are excellent for irrigation. The graphical diagram of irrigated water (US Salinity Laboratory 1954) and the integrated effect of EC and SAR conclude that the groundwaters of the study area reveal that the groundwaters possess high salinity with low sodium. Further, these waters are rated as satisfactory for agricultural purposes. SAR is plotted against EC, which is designated as after US Salinity Laboratory 1954 and is illustrated in Fig. 5. In the present study, all the water samples are falling under high specific conductance and low sodium [C3S1] as per US Salinity Laboratory (1954). The excess sodium in waters produces the undesirable effects of changing soil properties and reducing soil permeability (Kelly 1951). Hence, the assessment of sodium concentration is necessary while considering the suitability for irrigation. The degree to which irrigation water tends to enter into cation-exchange reactions in soil can be indicated by the sodium adsorption ratio (US Salinity Laboratory 1954). Sodium replacing adsorbed calcium and magnesium is a hazard as it causes damage to the soil structure. It becomes compact and impervious.

\section{Adjusted sodium adsorption ratio (adj.SAR)}

The high concentration of sodium in irrigation water may negatively affect the soil structure and decrease the soil hydraulic conductivity in fine-textured soil. The degree to

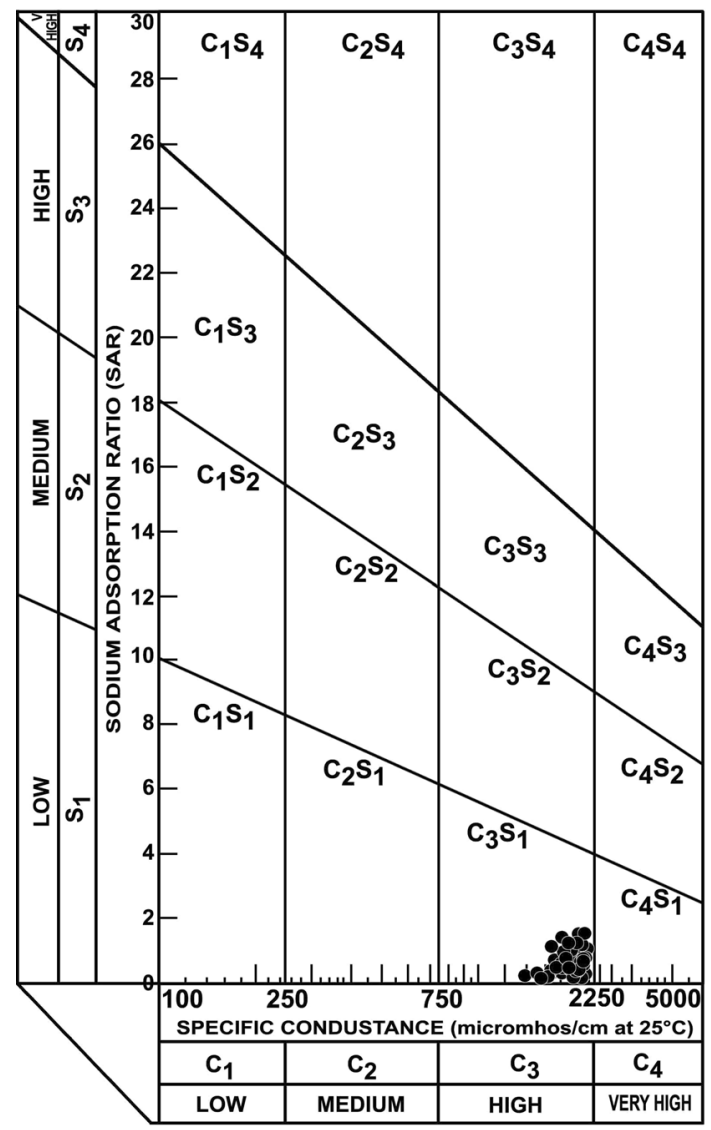

Fig. 5 Quality of groundwater samples in relation to salinity and sodium hazard (after US Salinity Laboratory 1954)

which sodium will be absorbed by a soil is a function of the amount of sodium to divalent cations $\left(\mathrm{Ca}^{2+}\right.$ and $\left.\mathrm{Mg}^{2+}\right)$ and is regularly stated by the sodium adsorption ratio (SAR) (Bouwer and Idelovitch 1987). This parameter is basically used for assessment of alkalinity hazard in irrigation water and it is ranging from 0.33 to 4.59 (Table 1). The result showed that the concern due to sodium hazard of the water became more emphatic because in all water samples adj.SAR is higher than SAR (Suarez 1981; Lesch and Suarez 2009).

This can be calculated with the following formula (Ayers and Westcot 1985):

Adjusted sodium adsorption ratio $(\operatorname{adj} . \mathrm{SAR})=\mathrm{SAR}$ $[1+(8.4-\mathrm{pHc})]$

$\mathrm{pHc}=(\mathrm{pK} 2-\mathrm{pKc})+\mathrm{p}(\mathrm{Ca}+\mathrm{Mg})+\mathrm{p}(\mathrm{Alk})$

where $\mathrm{pK} 2=$ negative logarithm of the second disassociation constant for carbonic acid, $\mathrm{pKc}=$ solubility constant for calcite, $p=$ negative logarithm of ion concentration. All ionic concentration is in meq/L.

Based on Ayers and Tanji (1981) classification, majority of samples have adj.SAR values are showing $<3$ and are safe for irrigation. The minimum value of adj.SAR is 0.33 and maximum value is 4.59 and average is about 1.79 . 


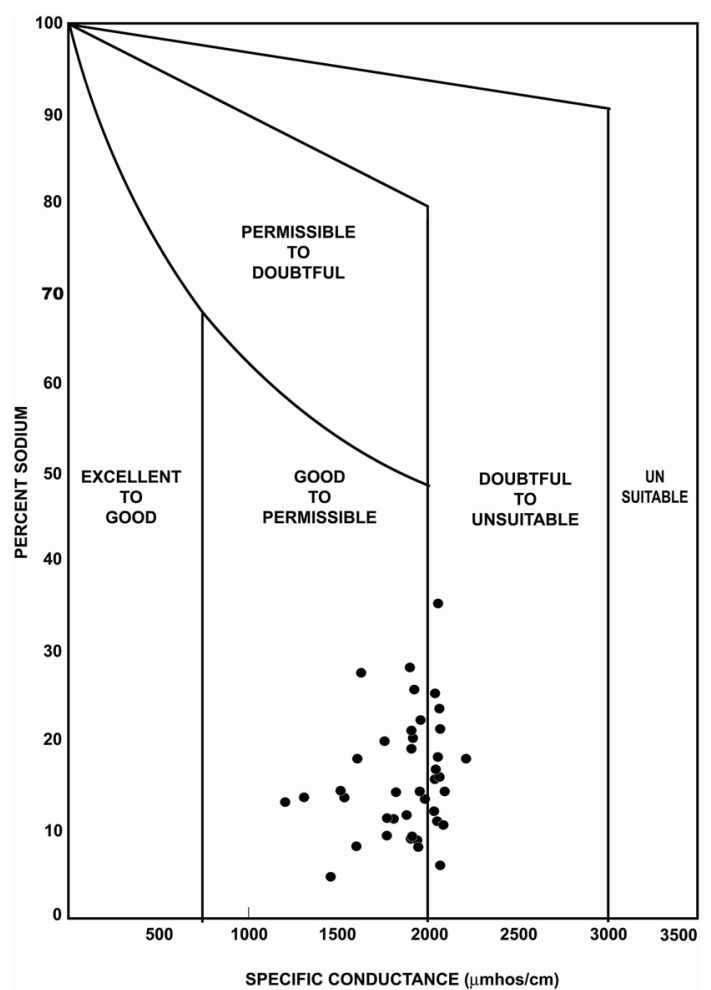

Fig. 6 Quality of water in relation to electrical conductivity and per cent sodium (Wilcox diagram)

\section{Sodium percentage}

Sodium concentration is important in classifying irrigation water. Soils containing a large proportion of sodium with carbonate as the predominant anion are termed alkali soils; those with chloride or sulphate as the predominant anion are saline soils. The role of sodium in the classification of groundwater for irrigation was emphasized because of the fact that sodium reacts with soil and as a result clogging of particles, thereby reducing the permeability (Domenico and Schwartz 1990; Todd and Mays 2005). When the concentration of $\mathrm{Na}^{+}$is high in irrigation water, $\mathrm{Na}^{+}$tends to be absorbed by clay particles displacing $\mathrm{Mg}^{2+}$ and $\mathrm{Ca}^{2+}$ ions. This exchange process of $\mathrm{Na}^{+}$in water for $\mathrm{Ca}^{2+}$ and $\mathrm{Mg}^{2+}$ in soil reduces the permeability and eventually results in soil with poor internal drainage. Hence, the assessment of sodium concentration is necessary while considering the suitability for irrigation. The $\mathrm{Na} \%$ is calculated using the formula given as follows:

$\% \mathrm{Na}=\frac{(\mathrm{Na}+\mathrm{K})}{(\mathrm{Ca}+\mathrm{Mg}+\mathrm{Na}+\mathrm{K})} \times 100$

where all ionic concentrations are expressed in meq/l.

In the present study, the per cent sodium values ranges from 4.73 to 35.03 with a mean value of about 15.86 (Table 1). Wilcox's (1955) diagram is adopted for classification of irrigation, wherein the EC is plotted against
$\mathrm{Na} \%$ (Fig. 6). Based on Wilcox classification, $65 \%$ samples belong to the good to permissible category and remaining $35 \%$ samples belong to doubtful to unsuitable category.

\section{Potential salinity}

Potential salinity is defined as the chloride concentration plus half of the sulphate concentration. Doneen (1954) explained that the suitability of water for irrigation is not dependent on soluble salts. It is true that the low solubility salts may precipitate in the soil and accumulate with each successive irrigation, whereas the concentration of highly soluble salts increases the soil salinity (Doneen 1962). The potential salinity of the water samples ranges from 0.72 to 6.13 (Table 1).

\section{Residual sodium carbonate (RSC)}

It is another parameter used to classify groundwater for irrigation purposes (Siddiqui et al. 2005). The RSC in groundwater is mainly due to the higher concentration of bicarbonate ions, which precipitates $\mathrm{Ca}^{2+}$ and $\mathrm{Mg}^{2+}$ ions as their carbonates and elevates $\mathrm{Na}^{+}$ions, which increases the sodium carbonate in the groundwater (Srinivas et al. 2014). In addition to the total dissolved solids, the relative abundance of sodium with respect to alkaline earths and boron and the quantity of bicarbonate and carbonate in excess of alkaline earths also influence irrigation water quality. This excess is denoted by residual sodium carbonate and determined as suggested by Richards (1954). The water with high RSC has high $\mathrm{pH}$ and land irrigated by such waters becomes infertile owing to deposition of sodium carbonate as indicated by the black colour of the soil (Eaton 1950). In waters having high concentration of bicarbonate, there is tendency for calcium and magnesium to precipitate as the water in the soil becomes more concentrated. As a result, the relative proportion of sodium in the water is increased in the form of sodium carbonate.

RSC is calculated using the following formula:

$\mathrm{RSC}=\left(\mathrm{HCO}_{3}+\mathrm{CO}_{3}\right)-(\mathrm{Ca}+\mathrm{Mg})(\mathrm{meq} / \mathrm{l})$

Lloyd and Heathcoat (1985) have classified irrigation water based on RSC as (1) suitable $(<1.25)(2)$ marginal $(1.25-2.5)$ and (3) not suitable ( $>2.5)$. In the present study, from Table 1, it can be interpreted that the groundwaters in the study area shows RSC values of ranging from -3.92 to $1.03 \mathrm{meq} / \mathrm{l}$. Based on RSC values, all 40 samples have values less than 1.25 and are safe for irrigation. 


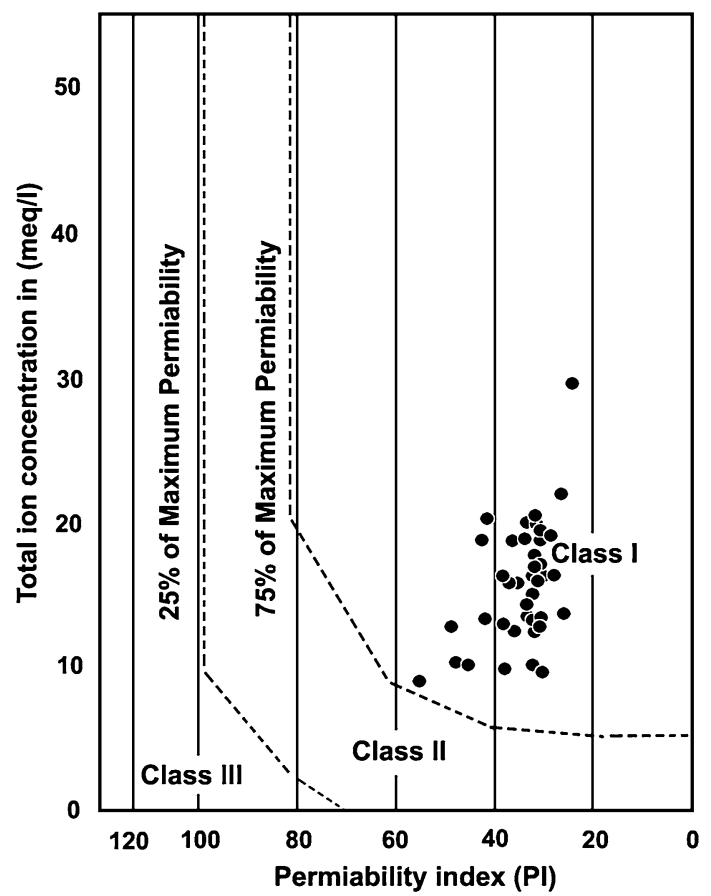

Fig. 7 Doneen's diagram of groundwater quality

\section{Permeability index (PI)}

The soil permeability is affected by the long-term use of irrigation water as it is influenced by $\mathrm{Na}^{+}, \mathrm{Ca}^{2+}, \mathrm{Mg}^{2+}$ and $\mathrm{HCO}_{3}{ }^{-}$content of the soil. Doneen (1964) and WHO (2006) gave a criterion for assessing the suitability of groundwater for irrigation based on the PI, where concentrations are in meq/l.

$\mathrm{PI}=\left(\mathrm{Na}^{+}+\sqrt{ } \mathrm{HCO}_{3}^{-} \times 100 /\left(\mathrm{Ca}^{2+}+\mathrm{Mg}^{2+}+\mathrm{Na}^{+}\right)\right.$

The analytical data are plotted on the Doneen's chart (Fig. 7). All samples were plotted in Class I zone, indicating that all groundwater samples were suitable for irrigation in terms of the PI (Domenico and Schwartz 1990).

\section{Kelly's ratio}

Groundwater was also classified for irrigation based on Kelly's ratio in this study. Sodium measured against calcium and magnesium was considered by Kelly (1940) and Paliwal (1967) to calculate this parameter. A Kelly's ratio of more than one indicates excessive sodium in waters, which is not suitable for irrigation. Kelly's ratio can be calculated as follows:

$\{$ Kelly's ratio $=\mathrm{Na} /(\mathrm{Ca}+\mathrm{Mg})\}$

where all the ionic constituents are expressed in meq/l.
From Table 1, it can be suggested that the Kelly's ratio varies from 0.04 to 0.50 , demonstrating that all water samples are suitable for irrigation.

\section{Sources of major ions}

Correlation analysis and bivariate diagrams are helpful in understanding the processes of groundwater chemical evolution (Wu et al. 2014; Tiwari and Singh 2014). In this study, bivariate diagrams were generated based on Pearson correlation analysis to get a better understanding of the groundwater chemical evolution processes, and the results are shown in Fig. 8.

The correlation and trend line analyses between the groundwater constituents are exhibited in Fig. 8. The existence of a very strong correlation exist between $\mathrm{HCO}_{3}{ }^{-}$ and $\mathrm{Ca}^{2+}+\mathrm{Mg}^{2+}(r=0.92)$; between $\mathrm{HCO}_{3}{ }^{-}+\mathrm{SO}_{4}{ }^{2-}$ and $\mathrm{Ca}^{2+}+\mathrm{Mg}^{2+}(r=0.95)$; total cations and $\mathrm{Ca}^{2+}$ and $\mathrm{Mg}^{2+}(r=0.96)$. There is a strong relation between $\mathrm{HCO}_{3}{ }^{-}$and $\mathrm{Ca}$ (0.69); $\mathrm{Cl}^{-}+\mathrm{SO}_{4}{ }^{2-}$ vs $\mathrm{Na}^{+}+\mathrm{K}^{+}$ $(r=0.65) ; \mathrm{Cl}^{-}+\mathrm{SO}_{4}{ }^{2-}$ vs $\mathrm{Ca}+\mathrm{Mg}(r=0.63)$.

The plot of $\mathrm{Ca}^{2+}+\mathrm{Mg}^{2+}$ vs $\mathrm{HCO}_{3}{ }^{-}$shows a abundance of $\mathrm{Ca}^{2+}+\mathrm{Mg}^{2+}$ relative to $\mathrm{HCO}_{3}{ }^{-}$, and Fig. 8 b shows that the abundance of $(\mathrm{Ca}+\mathrm{Mg})$ in most of the groundwater samples probably can be attributed to carbonate weathering. The climate also plays a vital role in the arid and semi arid areas. The plots between total cations and $\mathrm{Ca}+\mathrm{Mg}$ as well as $\mathrm{Na}+\mathrm{K}$ are 0.96 and 0.40 , respectively (Fig. 8d, e).

The chemical composition of groundwater is the imprints of the rock-water interaction and chemical processes. Generally, the presence of rock-water interaction was identified using TDS vs $\mathrm{Na} /(\mathrm{Na}+\mathrm{Ca})$ and TDS vs $\mathrm{Cl} /$ $\left(\mathrm{Cl}+\mathrm{HCO}_{3}\right)$ scatter diagrams as reported by Gibbs (1970) (Fig. 9). These diagrams are widely employed to assess the functional sources of dissolved chemical constituents, such as precipitation, rock, and evaporation dominance. In these diagrams, samples falling in the centre of the curve are derived from rock-water interaction. Figure 9 presents Gibbs plots of Group (A) and (B) groundwater quality data of Tummalapalle area.

This observation showed the involvement of silicate weathering in the geochemical processes, which contribute mainly sodium, calcium and potassium ions to the groundwater (Stallard and Edmond 1983; Sarin et al. 1989).

\section{Conclusions}

The groundwater in Tummalapalle area is alkaline in nature. In majority of the groundwater samples, concentrations of alkaline earths $\left(\mathrm{Ca}^{2+}+\mathrm{Mg}^{2+}\right)$ exceed alkali 

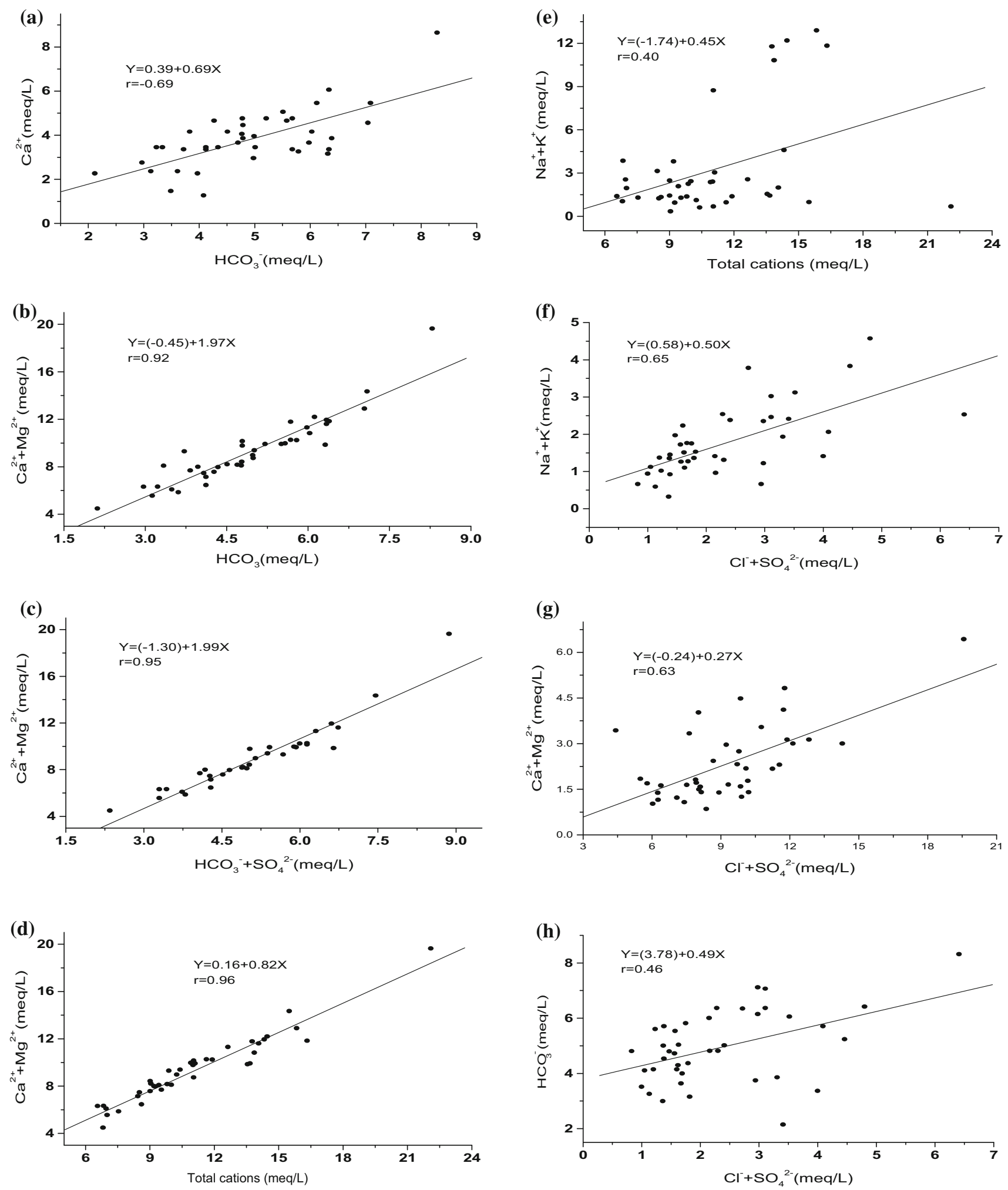

Fig. 8 Scatter plots between. a $\mathrm{HCO}_{3}{ }^{-}$vs $\mathrm{Ca}^{2+} ; \mathbf{b} \mathrm{HCO}_{3}{ }^{-}$vs $\mathrm{Ca}^{2+}+\mathrm{Mg}^{2+} ; \mathbf{c} \mathrm{HCO}_{3}{ }^{-}+\mathrm{SO}_{4}{ }^{2-} \mathrm{vs} \mathrm{Ca}^{2+}+\mathrm{Mg}^{2+}$; d total cations vs $\mathrm{Ca}^{2+}+$ $\mathrm{Mg}^{2+}$; e total cations vs $\mathrm{Na}^{+}+\mathrm{K}^{+} ; \mathbf{f ~ C l}^{-}+\mathrm{SO}_{4}{ }^{2-} \mathrm{vs} \mathrm{Na}^{+}+\mathrm{K}^{-} ; \mathbf{g ~ C l}^{-}+\mathrm{SO}_{4}{ }^{2-} \mathrm{vs} \mathrm{Ca}^{2+}+\mathrm{Mg}^{2+} ; \mathbf{h ~ C l}^{-}+\mathrm{SO}_{4}{ }^{2-} \mathrm{vs} \mathrm{HCO}_{3} \mathrm{HC}^{-}$

cations $\left(\mathrm{Na}^{+}+\mathrm{K}^{+}\right)$and $\mathrm{HCO}_{3}^{-}$dominate over $\left(\mathrm{SO}_{4}{ }^{2-}+\mathrm{Cl}^{-}\right)$. $\mathrm{Ca}-\mathrm{Mg}-\mathrm{HCO}_{3}$ is the dominant hydrogeochemical facies. The statistical analyses were used for determining the groundwater quality variations. Water chemistry of the study area strongly reflects the dominance of weathering of rock-forming minerals. The Gibbs 

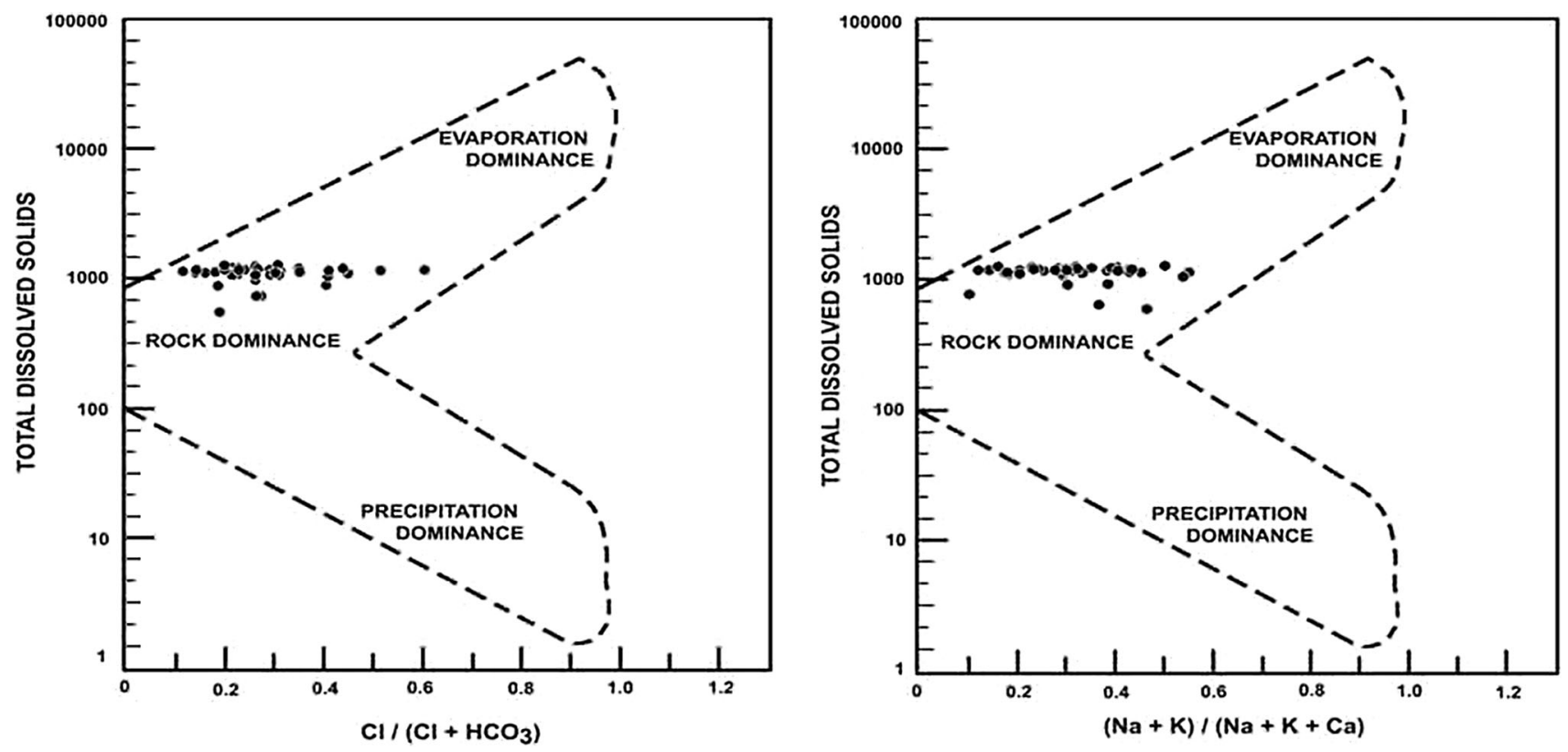

Fig. 9 Mechanism controlling the quality of groundwater

diagram revealed that the hydrochemistry of groundwater falls in the rock weathering region and is due to dissolution with rock-forming minerals. Pearson correlation analysis reveals that natural processes such as mineral dissolution/precipitation and cation exchange are dominant factors influencing the groundwater chemistry. The high contribution of $\left(\mathrm{Ca}^{2+}+\mathrm{Mg}^{2+}\right)$ to the total cations suggest that the chemical composition of the water is largely controlled by bicarbonate weathering with limited contribution from silicate weathering. The Piper diagram has revealed that all the samples are characterized as carbonate hardness (secondary alkalinity) exceeds $50 \%$ and are due to the dolomitic rocks which are responsible for release of chemical elements into the groundwaters of the study area.

In this study, the assessment of groundwater for irrigational uses has been evaluated on the basis of various parameters. Sodium adsorption ratio (SAR) values are to be less than 10; and adj. SAR also less than 3; Residual sodium carbonate (RSC) values on the whole are less than $1.25 \mathrm{meq} / \mathrm{l}$; Permeability index (PI) are also in acceptable range for irrigation. All these parameters indicating the water samples of the study are good for irrigation. According to the as per USSL diagram all water samples are falling under very high specific conductance and low sodium [C3S1] and are suitable for irrigation. The Wilcox classification has shown $65 \%$ of groundwater under "good to permissible" zone. Thus, the overall groundwater quality in the basin is fresh and suitable for irrigation use. The plots of dissolved solids (TDS) and total hardness (TH) suggest that about $12.5 \%$ of the samples are suitable for human consumption because they are fresh water with acceptable degrees of hardness. Suitable water treatment process such as water softening, ion exchange, and demineralization should be applied to reduce the concentration of contaminants. The various indices derived in the study indicate that the most of groundwater of the study area is suitable for agriculture irrigation use. The long-term use of such groundwater for irrigation will induce sodium hazard to soils. It will have negative impacts on the yields of crops and properties of soils. However, mixing of low and high salinity water is recommended before irrigation to reduce the salinity hazard in local areas.

Open Access This article is distributed under the terms of the Creative Commons Attribution 4.0 International License (http:// creativecommons.org/licenses/by/4.0/), which permits unrestricted use, distribution, and reproduction in any medium, provided you give appropriate credit to the original author(s) and the source, provide a link to the Creative Commons license, and indicate if changes were made.

\section{References}

APHA (2012) Standard methods for the examination of water and wastewater, 22nd edn. American Public Health Association, New York

Ayers RS, Tanji KK (1981) Agronomic aspects of crop irrigation with wastewater, Pro Water Forum 81, 1. ASCE, New York, pp 579-586

Ayers RS, Westcot DW (1985) Water quality for agriculture, irrigation and drainage. Paper No. 29. Food and Agriculture Organization of the United Nations, Rome, pp 1-117 
Basu H (2007) Geological and geochemical aspects of the Gulcheru Formation in the southwestern margin of the Cuddapah Basin and its potentiality for Uranium Minerali-zation. J Geol Soc India 70(4):686-688

Bhattacharya T, Chakraborty S, Neha Tuck (2012) Physico chemical Characterization of ground water of Anand district, Gujarat, India. I Res J Environ Sci 1(1):28-33

Bouwer H, Idelovitch E (1987) Quality requirement for irrigation with sewer water. J Irrig Drain Eng 113(4):516-535

Brindha K, Rajesh R, Murugan R, Elango LN, Nair RN (2010) Spacial and seasonal variation in groundwater level and uranium concentration in Peddagattu and Seripalli area of Nalgonda district, Andhra Pradesh, India.In: 17th National Symposium on Environment

Central Ground Water Board (CGWB) (2007) Ground water information. Kadapa District, Andhra Pradesh, p 45

Central Ground Water Board (CGWB) (2013) Ground water brochure, YSR District (Kadapa), Andhra Pradesh, p 22

Chadha DK (1999) A proposed new diagram for geochemical classification of natural water and interpretation of chemical data. Hydrogeol J 7:431-439

Cidu R, Biddau R, Nieddu G (2007) Rebound at Pb-Zn mines hosted in carbonate aquifers, influence on the chemistry of ground water. Mine Water Environ 26:88-101

Compton A (2011) A review of rationale for EC and SAR standards. Helena, MT, Montana Dept. of Environmental Quality, pp 1-34

Davis SN, Dewiest RJM (1967) Hydrogeology. Wiley, New York

Domenico PA, Schwartz FW (1990) Physical and chemical hydrogeology. Wiley, New York

Doneen LD (1954) Salination of soil by salts in the irrigation water. Am Geophys Union Trans 35:943-950

Doneen LD (1962) The influence of crop and soil on percolating water. In: Proceedings of 1961. Biennial conference on Groundwater Recharge, pp 156-163

Doneen LD (1964) Water quality for agriculture. Department of Irrigation, University of California, Davis, p 48

Durov SA (1948) Natural waters and graphic representation of their composition Dokl. Akad Nauk SSSR 59:87-90

Eaton FM (1950) Significance of carbonates in irrigated waters. Soil Sci 69:127-128

Geological Survey of India (GSI) (2001) District resource map. Cuddapah District, Andhra Pradesh

Gibbs RJ (1970) Mechanisms controlling world water chemistry. Science 170:1081-1090

Gupta DP, Sunita Saharan JP (2009) Physiochemical analysis of groundwater of selected area of Kaithal City (Haryana) India. Researcher 1(2): 1-5

Hem JD (1985) Study and interpretation of the chemical characteristics of natural water. USGS Water Supply Paper, p 2254

Jain CK, KKS Bhatia, CP Kumar, BP Purandara (2001) Ground water quality in Malprabha river basin, Karnataka. Technical Report, 2000-2001. National Institute of Hydrology, Roorkee

Kelly WP (1940) Permissible composition and concentration of irrigated waters. In: Proceedings of the ASCF, p 607

Kelly WP (1951) Alkali soils-their formation, properties and reclamation. Reinhold Publ, New York

Kuipers JR, MacHardy K, Merschat W, Myers T (2004) Coal bed methane-produced water, management options for sustainable development. In: 11th International Petroleum Environmental Conference, October 12-15, Albuquerque

Lesch SM, Suarez DL (2009) A short note on calculating the adjusted SAR index. Am Soc Agric Biol Eng 52(2):493-496

Li P, Qian H, Wu JH (2011) Hydrochemical characteristics and evolution laws of drinking groundwater in Pengyang County, Ningxia, Northwest China. E J Chem 8(2):565-575
Li P, Wu J, Qian H (2012) Groundwater quality assessment based on rough sets attribute reduction and TOPSIS method in a semi-arid area, China. Environ Monit Assess 184(8):4841-4854

Li P, Wu J, Qian H (2013a) Assessment of groundwater quality for irrigation purposes and identification of hydrogeochemical evolution mechanisms in Pengyang County, China. Environ Earth Sci 69(7):2211-2225

Li P, Qian H, Wu J, Zhang Y, Zhang H (2013b) Major ion chemistry of shallow groundwater in the Dongsheng coalfield, Ordos Basin, China. Mine Water Environ 32(3):195-206

Li P, Wu J, Qian H (2014a) Hydrogeochemistry and quality assessment of shallow groundwater in the Southern Part of the Yellow River Alluvial Plain (Zhongwei Section), China. Earth Sc Res J 18(1):27-38

Li P, Qian H, Wu J, Chen J, Zhang Y, Zhang H (2014b) Occurrence and hydrogeochemistry of fluoride in shallow alluvial aquifer of Weihe River, China. Environ Earth Sci 71(7):3133-3145

Li P, Qian H, Howard KWF, Wu J (2015) Building a new and sustainable "Silk Road economic belt". Environ Earth Sci 74(10):7267-7270

Li P, Wu J, Qian H (2016a) Hydrochemical appraisal of groundwater quality for drinking and irrigation purposes and the major influencing factors: a case study in and around Hua County, China. Arab J Geosci 9(1):15

Li P, Wu J, Qian H, Zhang Y, Yang N, Jing L, Yu P (2016b) Hydrogeochemical characterization of groundwater in and around a wastewater irrigated forest in the southeastern edge of the Tengger Desert, Northwest China. Expo Health 8(3):331-348

Li P, Zhang Y, Yang N, Jing L, Yu P (2016c) Major ion chemistry and quality assessment of groundwater in and around a mountainous tourist town of China. Expo Health 8(2):239-252

Li P, Li X, Meng X, Li M, Zhang Y (2016d) Appraising groundwater quality and health risks from contamination in a semiarid region of northwest China. Expo Health 8(3):361-379

Lloyd JW, Heathcoat JA (1985) Natural inorganic hydrochemistry in relation to groundwater, an introduction. Oxford University, New York

Mahesh HM, Avadhani DN, Someshekarappa HM, Karunakara N, Narayana Y, Siddappa K (2001) Uranium concentration in water samples in the environment of coastal Karnataka and Kaiga. Proc Nat Sem Atom Energ Ecol Environ, 113-116

Manish Kumar M, Kalpana K, Ramanathan AL, Rajinder S (2007) A comparative evaluation of groundwater suitability for irrigation and drinking purposes in two intensively cultivated districts of Punjab, India. Environ Geol 53:553-574

Mitra BK, Sasaki C, Enari K, Matsuyama N, Fujita M (2007) Suitability assessment of shallow groundwater for agriculture in sand dune area of northwest Honshu Island Japan. Appl Ecol Environ Res 5(1):177-188

Nagaraju A, Suresh S, Killham K, Hudson-Edwards K (2006) Hydrogeochemistry of waters of Mangampeta a barite mining area, Cuddapah basin, Andhra Pradesh, India. Turkish J Eng Env Sci 30:203-219

Nagaraju A, Sunil Kumar K, Thejaswi A, Hemalatha T (2013) Groundwater quality assessment, A case study of Sanayapalem area, Andhra Pradesh, India. Elixir Pollution 63:18127-18133

Nagaraju A, Sunil Kumar K, Thejaswi A, Sharifi Z (2014a) Statistical analysis of the hydrogeochemical evolution of groundwater in the Rangampeta area, Chittoor District, Andhra Pradesh, South India. Am J Water Resour 2(3):63-70

Nagaraju A, Sunil Kumar K, Thejaswi A (2014b) b) Assessment of groundwater quality for irrigation, a case study from Bandalamottu lead mining area, Guntur District, Andhra Pradesh, South India. Appl Water Sci 4:385-396 
Nagaraju A, Balaji E, Thejaswi A, Sun L (2015) Quality evaluation of groundwater in Mulakalacheruvu area, Chittoor district, Andhra Pradesh, South India based on hydrogeochemistry. Fresenius Env Bull 24:4496-4503

Nagaraju A, Sharifi Z, Balaji E (2016a) Statistical and analytical evaluation of groundwater quality of Tirupati Area, Chittoor District, Andhra Pradesh, South India. J Geol Soc India $88: 222-234$

Nagaraju A, Thejaswi A, Sun L (2016b) Statistical analysis of high fluoride groundwater hydrochemistry in Southern India: quality assessment and implications for source of fluoride. Environ Eng Sci 33:471-477

Nagaraju A, Balaji E, Thejaswi A (2016c) Hydrogeochemical evaluation of groundwater in certain parts of Vinukonda area, Guntur District, Andhra Pradesh, South India. Fresenius Environ Bull 25:1519-1532

Paliwal KV (1967) Effect of gypsum application on the quality of irrigation waters. Madras Agric J 59:646-647

Piper AM (1944) A graphical procedure in the geochemical interpretation of water analysis. Trans Am Geophys Union 25:914-923

Piper AM (1953) A graphic procedure I the geo-chemical interpretation of water analysis, USGS Groundwater Note no. 12

Raghunath HM (1987) Groundwater, 2nd edn. New Delhi, Wiley Eastern Limited, p 563

Ravikumar P, Somashekar RK (2013) A geochemical assessment of coastal groundwater quality in the Varahi river basin, Udupi District, Karnataka State, India. Arab J Geosci 6:1855-1870

Richards LA (1954) Diagnosis and improvement of saline and alkali soils, 60. US Department of Agricultural Handbook, Washington DC, p 160

Sadashivaiah C, Ramakrishnaiah CR, Ranganna G (2008) Hydrochemical analysis and evaluation of groundwater quality in Tumkur Taluk, Karnataka State, India. Int J Environ Res Public Health 5(3):158-164

Sarin MM, Krishnaswamy S, Dilli K, Soma-yajulu BLK, Moore WS (1989) Major ion chemistry of the Ganga-Brahmaputra River System: weathering process and fluxes to the Bay of Bengal". Geochim Cosmochim Acta 53:997-1009

Siddiqui A, Naseem S, Jalil T (2005) Groundwater quality assessment in and around Kalu Khuhar, super highway, Sindh, Pakistan. J Appl Sci 5(7):1260-1265

Srinivas Y, Hudson Oliver D, Stanley Raj A, Chandrasekar N (2014) Quality assessment and hydrogeochemical characteristics of groundwater in Agastheeswaram taluk, Kanyakumari district, Tamil Nadu, India. Chin J Geochem 33:221-235
Stallard RF, Edmond JM (1983) Geochemistry of the Amazon: 2. The influence of geology and weathering environment on the dissolved load. J Geophys Res Ocean 88(14):9671-9688

Suarez DL (1981) Relation between pHc and sodium adsorption ratio (SAR) and an alternative method of estimating SAR of soil and drainage waters. SSSA J 45(3):469-475

Suresh S, Dinakar N, Prasad TNVKV, Nagajyothi PC, Damodharam T, Nagaraju A (2007) Effects of a barite mine on groundwater quality in Andhra Pradesh, India. Mine Water Environ 26:119-123

Tiwari AK, Singh AK (2014) Hydrogeochemical investigation and groundwater quality assessment of Pratapgarh District, Uttar Pradesh. J Geol Soc India 83:329-343

Todd DK, Mays LW (2005) Groundwater hydrology, 3rd edn. Wiley, Hoboken, p 656

Tripathi RM, Jha VN, Sahoo SK, Sethy NK, Shukla AK, Puranik VD, Kushwaha HS (2011) Study of distribution of $226 \mathrm{Ra}$ in groundwater near the uranium industry of Jharkhand, India. Radiat Prot Dosim 148(2):211-218

US Salinity Laboratory (1954) Diagnosis and improvement of saline and alkaline soils. US Dept. of Agriculture. Hand Book, 60, 160

Walton WC (1970) Groundwater resources evaluation. McGraw Hill Book Co., New York

Wanda E, Monjerezi M, Mwatseteza JF, Kazembe LN (2011) Hydrogeochemical appraisal of groundwater quality from weathered basement aquifers in Northern Malawi. Phys Chem Earth Parts $\mathrm{A} / \mathrm{B} / \mathrm{C}$ 36(14-15):1197-1207

WHO (2006) Guideline for drinking water quality, 1st Ed. Addendum to the 3rd edn, Recommendations. World Health Organization, Geneva, p 515

Wilcox LV (1955) Classification and use of Irrigation water. US Dept of Agriculture, Washington, Circular No. 969:19

Wu J, Sun Z (2016) Evaluation of shallow groundwater contamination and associated human health risk in an alluvial plain impacted by agricultural and industrial activities, mid-west China. Expo Health 8:311-329

Wu J, Li P, Qian H, Duan Z, Zhang X (2014) Using correlation and multivariate statistical analysis to identify hydrogeochemical processes affecting the major ion chemistry of waters: case study in Laoheba phosphorite mine in Sichuan, China. Arab J Geosci 7(10):3973-3982

Wu J, Li P, Qian H (2015) Hydrochemical characterization of drinking groundwater with special reference to fluoride in an arid area of China and the control of aquifer leakage on its concentrations. Environ Earth Sci 73(12):8575-8588 